\title{
НОВЫЕ ТЕНДЕНЦИИ В РАССТАНОВКЕ ПОЛИТИЧЕСКИХ СИЛ ФРГ (НА ПРИМЕРЕ ИЗБИРАТЕЛЬНОЙ КАМПАНИИ 2021 Г.)
}

\author{
А. В. ШАРАПО \\ Белорусский государственный университет \\ Минск, Республика Беларусь
}

\begin{abstract}
Аннотация. В статье осуществляется сравнительный анализ итогов парламентских выборов в ФРГ в 2021 г. Автором также рассматриваются последствия данной избирательной кампании, которые заключались в значительном изменении политического потенциала ведущих германских партий, ухода из политической жизни Германии многолетнего канцлера А. Меркель и формирования новой правящей коалиции. В новое правительство ФРГ вошли три политические партии: социал-демократы, свободные демократы и зеленые. Федеральным канцлером был избран лидер СДПГ О. Шольц, который представил правительственную программу, нацеленную на продвижение обновленной стратегии развития ФРГ в последующие десятилетия.

Несмотря на то, что анализ итогов и последствий парламентских выборов в ФРГ в 2021 г. представляет значительный интерес для комплексного изучения различными исследователями, актуальность и новизна событий и процессов, которые проходили в ФРГ весной - осенью 2021 г., определяют явно недостаточное их освещение в научных публикациях.

Итоги и последствия избирательной кампании 2021 г. требуют дальнейшего всестороннего исследования в связи с их важностью для определения будущих направлений как внутренней, так и внешней политики современной Германии, которая способна оказывать значимое влияние на европейскую и мировую политику, в том числе путем определения стратегии развития ЕС и воздействия на решения иных европейских государств.
\end{abstract}

Ключевые слова: ФРГ; внутренняя политика Германии; СДПГ; ХДС; «Зеленые»; СвДП; парламентские выборы; правящая коалиция.

Образец цитирования: Шарапо $A$. B. Новые тенденции в расстановке политических сил ФРГ (на примере избирательной кампании 2021 г.) // Актуальные проблемы международных отношений и глобального развития: сб. науч. статей. Минск, 2021. Вып. 9. С. 37-53. https://doi.org/10.33581/2311-9470-2021-9-37-53

Введение. Прошедшая 8 декабря 2021 г. церемония приведения к присяге нового правительства ФРГ завершила одну из самых драматичных, полных внутрипартийных интриг и непредсказуемых по итогам избирательных кампаний Германии в XXI в. По ее итогам Социал-демократическая партия (СДПГ) набрала 25,7\% голосов; Хри- 
стианско-демократический и Христианско-социальный союз - 24,1\%; «Зеленые» - 14,8\%; Свободная демократическая партия - 11,5\%; «Альтернатива для Германии» - 10,3\%. Левые набрали лишь 4,9\% и вошли в бундестаг лишь благодаря трем прямым мандатам, которые их кандидаты получили в округах. Места в парламенте разделились следующим образом: СДПГ - 206 (на 53 больше, чем в 2017 г., блок ХДС/ХСС - 196 мест (на 50 меньше), «Зеленые» - 118 мест (на 51 больше), СвДП - 92 места (на 12 больше), «Альтернатива для Германии» - 83 места (на 11 меньше), «Левые» - 39 мест (на 30 меньше) ${ }^{1}$.

Сравнительный анализ итогов и последствий парламентских выборов в ФРГ в 2021 г. представляет значительный интерес для комплексного изучения изменения внутри- и внешнеполитических приоритетов Германии в условиях трансформации германского общества и изменения его политических настроений.

Цель данной статьи - выявление, систематизация и обобщение основных итогов и последствий парламентских выборов 2021 г. для партийной системы ФРГ.

Хронологические рамки изучаемых событий и явлений включают весну - осень 2021 гг., когда в Германии развернулась предвыборная кампания, приведшая к смене правящей коалиции и изменению курса правительства во внутренней и внешней политике.

Актуальность проведенного исследования определяется тем фактором, что политические изменения в ФРГ способны затронуть всю европейскую политику, поскольку именно Германия сегодня обладает наибольшим влиянием на определение стратегии развития ЕС и воздействует на решения других европейских государств.

Методы исследования. В работе над статьей исследователь исходил из базовых принципов объективности и историзма, опираясь на применение основных общенаучных (анализ, синтез, сравнение, обобщение, дедукция), а также специальных исторических методов и, в первую очередь историко-генетического историко-сравнительного, историко-типологического. В основе исследования лежало сочетание структурного и системного методологических подходов.

Объектом исследования являются долгосрочные последствия изменения политического ландшафта ФРГ в 2021 г. в результате парламентских выборов и формирования новой коалиции.

\footnotetext{
${ }^{1}$ Bundestagswahl 2021 // Tagesschau.de [Электронный ресурс]. 2021. URL: https://www.tages schau.de/wahl/archiv/2021-09-26-BT-DE/index.shtml (дата обращения: 01.12.2021).
} 
Предмет исследования - характерные особенности проведения избирательной кампании 2021 г. и ее основных итогов.

Обзор литературы по теме. Исследование основных направлений политических, социальных и экономических изменений в Германии традиционно относится к числу важнейших тем в исследованиях экспертов - международников как в Республике Беларусь, так и за ее пределами. Эта проблематика занимала значительное место в научных публикациях и аналитических обзорах ведущих российских исследователей - германистов. В России сформировалась наиболее развитая на постсоветском пространстве школа изучения современной Германии, теоретико-методологическую основу которой составила советская традиция комплексного изучения истории и актуального развития германского общества.

Особое место среди российских германистов занимает известный исследователь Н. В. Павлов - автор фундаментальной монографии «Внешняя политика канцлера А. Меркель (2005-2017)», в которой он фактически подвел итог эволюции внешнеполитического курса Германии в эпоху нахождения у власти этого политика - тяжеловеса, мнение которой формировало позицию всего ЕС по важнейшим вопросам мировой политики [1].

Изменение экономической основы немецкого общества, которое оказало очень значимое влияние на формирование нового политического ландшафта ФРГ после выборов, стало предметом изучения таких известных российских исследователей - германистов, как В. Б. Белов, И. Ф. Максимычев, Н. К. Меден, А. В. Огнева, С. В. Погорельская, Е. П. Тимошенкова, Ф. О. Трунов. Результатом их совместного исследования стала фундаментальная коллективная монография «Экономика и политика Германии: через год после выборов», основные положения которой актуальны и сегодня [9].

Для белорусских экспертов - германистов характерен интерес к определению взаимосвязи важнейших внутри- и внешнеполитических процессов в ФРГ. Этой широкой проблематике были посвящены такие публикации профессора ФМО БГУ В. В. Фрольцова, как статьи «Внешнеполитические цели и задачи четвертого правительства А. Меркель», «Реакция ФРГ на «цветные революции» в постсоветских государствах (2003-2005)», «Germany's foreign policy in the context of the multilateralism crisis in the 2010s: the main challenges and risks», «The Eastern and Southeastern European countries in the preelection programs of the key German parties 2017», «Russia, Ukraine, 
Belarus in the program documents of the three governments of Angela Merkel (2005-2017)» $[2 ; 4 ; 10 ; 11 ; 12]$. Ключевые взаимосвязи и взаимозависимости внутренней и внешней политики Германии в конце $\mathrm{XX}$ - XXI в. на примере формирования и реализации внешнеполитического курса ФРГ в отношении постсоветских государств были раскрыты в монографии В. В. Фрольцова «Постсоветские государства во внешней политике ФРГ (1991-2005)» [3].

Следует также отметить важные для подготовки этой статьи научные публикации ее автора, прежде всего, книгу «Политические системы и внешняя политика Германии, Австрии и Швейцарии», в которой были определены и детально охарактеризованы базовые принципы и приоритеты внешней политики ФРГ. Важные аспекты внешнеполитического процесса были рассмотрены также в статьях «ФРГ после выборов в Бундестаг 2017 г. в поиске новой модели развития», «Избирательная кампания 2017 г. в Германии: особенности межпартийной борьбы и проблемы формирования правительства» и «Особенности транзита власти в ФРГ: уроки прошлого и современность» $[5 ; 6 ; 7 ; 8]$.

Вместе с тем, актуальность и новизна изучаемых событий и процессов, которые проходили весной - осенью 2021 г., определяет явно недостаточное их освещение в научных публикациях, авторы которых только приступают к системному исследованию этих важных для будущего не только Германии, но и всей Европы явлений.

Результаты исследования. В немецких средствах массовой информации прошедшую избирательную кампанию сравнивают с многоактным политическим спектаклем под названием «Конец эпохи Меркель», за которым весь 2021 год наблюдала не только Германия, но и общественность других европейских стран.

Характерно, что многие аналитики расширяют название этого электорального спектакля, придавая ему более емкое звучание: «Конец эпохи Меркель - конец эпохи ХДС». Именно уход А. Меркель с политической сцены Германии предопределил кардинальное отличие этих выборов от предыдущих кампаний, внеся в предвыборную политическую борьбу новую систему координат. Как оказалось, окончание этого «спектакля» одни избиратели встретили аплодисментами, другие - скептическим молчанием.

Такое двойственное отношение немецкого электората к результатам выборов неслучайно. Оно является одним из последствий той политической и общественной трансформации, которая произошла за 
последние годы не только в Германии, но и в других европейских государствах. В основе таких кардинальных изменений - смена поколений и последующие сдвиги общественного сознания избирателей. Оценки этого явления разные: одни видят в нем объективное и прогрессивное развитие европейского сообщества, другие - угрозу европейской цивилизации.

Не обошла стороной эта трансформация и Германию, правда ее проявление здесь носит более «мягкий» характер и по своему влиянию на «большую политику» ФРГ ее пока нельзя отнести к категории значимых. Однако, что касается, образно говоря, «частностей», то здесь трансформационные последствия весьма ощутимы.

К такого рода «частностям» прежде всего можно отнести заметные сдвиги в области внутрипартийных и межпартийных отношений, a также кардинальные изменения структуры электорального поля Германии и политических настроений избирателей.

Рубеж XXI в. стал своеобразным водоразделом в политических предпочтениях немецкого электората, привыкшего делить политическое поле Германии в основном между двумя политическими партиями: Христианско-демократическим союзом (ХДС) и Социалдемократической партией (СДПГ).

В целом такая приверженность большого числа избирателей идеям этих двух партий обеспечивала для них более-менее приемлемый итог на выборах и неофициальное право поочередно приходить к власти. Избиратели - сторонники этих партий долгое время руководствовались лозунгом «если не они, то кто» и были в этом до определенной поры правы, так как реальной альтернативы этим партиям они не видели.

Однако с каждой избирательной кампанией XXI в. все более ярко стала проявляется другая картина - утрата этими партиями их главного атрибута - статуса общественного и партийного лидера и способности «идти в ногу со временем». Постепенно начали терять значимость основы их былых политических программ, базировавшихся на высоких идеях консерватизма и традиционализма. Электоральное пространство влияния ХДС и СДПГ в последние годы стало сужаться, уступая место другим набирающим популярность партийным платформам партий второго эшелона.

Динамика снижения популярности этих партий прослеживается на сопоставлении результатов избирательных кампаний в ФРГ первых послевоенных десятилетий и выборов 2021 г. 
Данная тенденция отображена в следующей таблице:

Процент поддержки

\begin{tabular}{|c|c|c|c|}
\hline & ХДС & СДПГ & суммарно \\
\hline 1949 г. & 25,2 & 29,2 & 54,4 \\
\hline 1953 г. & 36,4 & 28,8 & 65,2 \\
\hline 1957 г. & 39,7 & 31,8 & 71,5 \\
\hline $1961 \Gamma$. & 35,8 & 36,2 & 72,0 \\
\hline $1965 \Gamma$. & 38,1 & 39,3 & 77,4 \\
\hline $1969 \Gamma$. & 36,6 & 42,7 & 79,3 \\
\hline
\end{tabular}

Цит. no : Internazionale Politik (2005), 3, p. 18.

Результаты внушительные: суммарный процент электоральной поддержки этих партий в этот период составлял 65-68 \%.

Еще более показательны суммарные итоги выборов в 1970-е гг.: 1972 г. - 80\%, 1976 г. - 80\%, 1980 г. - 77,1\%. Консервативнолиберальные идеи обеих партий в то время несомненно пользовались популярностью у большинства избирателей.

Прошло полвека - период, полный важных событий и исторических свершений, среди которых наиболее значимым является объединение Германии. За это время страна под попеременным руководством ХДС и СДПГ продолжала оставаться наиболее развитым в мире государством и реальным политическим лидером в Евросоюзе.

Казалось бы, этими партиями набран такой политический потенциал, который не создает никаких причин для их озабоченности относительно будущих результатов на выборах 2021 г. Но, как оказалось, такая самоуверенность была напрасной. Сравнение итогов избирательной кампании 2021 г. с результатами полувековой давности показывают, насколько контрастны электоральные настроения того и нашего времени.

На последних выборах ХДС набрала лишь 24.1\% голосов - самый низкий показатель за всю историю, а СДПГ - 25,7\%. Суммарно $49,8 \%$. Как видим, падение популярности этих двух партий за полвека составило 36-48\%. Это дало основание предсказывать закат христианско- и социал-демократического правления в Германии.

Конечно, сторонники этих партий чтобы как-то сгладить негативное восприятие итоговых цифр могут в оправдание утверждать, что все же они более высокие по сравнению с другими партиями, тем более СДПГ получила право сформировать коалиционное правительство. Это действительно так, но дальнейший ход событий с отстране- 
нием ХДС от участия в правительственной коалиции, беспрецедентные трудности, с которыми при этом столкнулась победившая СДПГ, лавируя между уступками и достижениями, скорее говорят о наличии серьезных проблем в деятельности этих двух ведущих партий Германии.

Применительно к факту падения популярности ХДС и СДПГ многие задаются вопросом: почему на фоне того, что экономическое положение ФРГ продолжает оставаться лучшим в ЕС и ее политическое лидерство не вызывает ни у кого сомнения (заметим, что в XXI в. все это случилось за годы правления СДПГ - до 2005 г., а затем до наших дней - ХДС), сейчас итоги для этих партий оказались такими низкими.

По своему характеру причины снижения их популярности разнообразны. Они связаны со многими новыми факторами внутриполитической жизни самого немецкого общества, а также с кардинальными изменениями, произошедшими за последние годы на мировой сцене. На этом фоне видоизменяется электоральное поле Германии и происходит переориентировка электоральных предпочтений. Избиратели перестают видеть принципиальную разницу политических программах ХДС и СДПГ, и многие из них выбирают в качестве фаворитов другие партии. В электоральном плане это привело к размыванию «политического лица» каждой из этих партий, стиранию грани в восприятии избирателями их политических лозунгов. На возрастание такого рода электоральных настроений повлиял ряд факторов, среди которых можно выделить два наиболее показательных.

Во-первых, это все большее сближение концептуальных формулировок предвыборных программ и в целом политики СДПГ и ХДС.

Следует подчеркнуть, что ранее в послевоенной истории ФРГ именно отличие друг от друга общей политической направленности этих партий и понятные избирателям их партийные концепции предопределяли поочередную победу ХДС и СДПГ на выборах. Избиратели осознанно отдавали предпочтение той или иной из этих партий, видя в этом надежду на лучшее. Общая картина этого электорального соперничества: в 1949-1969 гг. Германией правила коалиция ХДСХСС; в 1969-1982 гг. - СДПГ; в 1982-1998 гг. - вновь ХДС-ХСС; в 1998 - 2005 гг. - СДПГ.

Однако, сейчас, как показывает сопоставление политических платформ этих партий в избирательной кампании 2021 г., немецкому электорату становится все труднее находить в них принципиальные 
различия. Прежде всего сближение в формулировках проявилось в разделах, касающихся стратегических вопросов внешнеполитической сферы - определение причин и путей разрешения актуальных мировых и региональных проблем. Если раньше даже при отсутствии антагонизма во внешнеполитических постулатах ХДС и СДПГ все-таки существовали серьезные различия, то в последние годы, наоборот, в вопросах геополитики обе партии находят все большее понимание.

В программе ХДС под названием «Стабильность и обновление. Вместе за современную Германию» немецкие консерваторы подчеркивают приверженность внешнеполитическому курсу А. Меркель: «США - наш важнейший партнер на международной арене. С президентом Байденом мы связываем шанс на прорыв в трансатлантических отношениях. ФРГ будет оставаться элементом системы ядерного сдерживания в рамках НАТО». В отношении России партия предлагает «конструктивно и решительно противостоять» Москве, но в то же время «искать пути диалога и сотрудничества там, где есть общие интересы» $2^{2}$.

Социал-демократы в своем манифесте «Для тебя. Наша программа будущего» также поддерживают членство ФРГ в НАТО с нюансом, что «параллельно Европейский союз должен становиться самостоятельнее в вопросах безопасности и оборонной политики». Они, как и ХДС, видят в союзе с США надежную гарантию своей безопасности и ратуют за укрепление атлантической солидарности».

Единственное небольшое отличие - более лояльное отношение СДПГ к России. В манифесте говорится: «Это в германских и европейских интересах, если мы сумеем вместе с Россией добиться прогресса в вопросах общей безопасности, разоружения и контроля над вооружениями, а также климата, устойчивого развития, энергетики и борьбы с пандемиями. При всей критике мы делаем ставку на готовность России к диалогу и к сотрудничеству». Заметим, что такая трактовка во многом перекликается с бывшей позицией ХДС в лице А. Меркель, однако в ходе избирательной кампании заявления кандидатов от этой партии, касающиеся России, носили более агрессивный характер.

Конечно, в определенной степени такая «солидарность» во внешнеполитической сфере обеих партий объясняется нынешним

\footnotetext{
2 Чем программы немецких партий завлекают избирателей // Российская газета [Электронный ресурс]. 2021. 25 августа. URL: https://rg.ru/2021/08/25/chem-programmy-nemeckih-partijzavlekaiut-izbiratelej.html (дата обращения: 01.12.2021).
} 
обострением международной обстановки, хотя и ранее было немало подобных периодов, и каждая из них находила свои ответы на возникающие проблемы, помогая избирателям предопределить их личные предпочтения в выборе «партии - фаворита» $)^{3}$.

Некоторую разницу в политических программах, правда, можно найти в разделах, касающихся экономических проблем (налогообложения, распределение бюджета и т.д., но эти расхождения настолько незначительны, что скорее затрудняют, чем облегчают процесс выбора). Они не дают ответа на такие волнующие сейчас немецкую общественность вопросы, как, например: почему ФРГ по линии ЕС должна нести большие расходы, чем другие страны с; почему в их стране наибольшее число иммигрантов и во что это обходится бюджету ФРГ; почему правительство не принимает должных мер в области защиты окружающей среды и т.п.

В целом концептуальное сближение программ ХДС и СДПГ привело к масштабному смещению немецкой политики влево и появлению на политическом поле Германии ряда новых партий правого и крайне правого толка.

Именно такой ситуацией и воспользовались партии второго эшелона, предоставив на суд избирателям свое видение политики Германии в условиях постоянно растущих угроз. Характерно, что во многом гипертрофированная детализация их программных установок нашла своих поклонников и, как оказалось, обеспечила приемлемый для некоторых из этих партий результат на выборах.

Вот, например, программные обещания партии «Союз90/Зеленые»: «Германию ждет социально-экологическая трансформация. Во имя приближения «зеленого» будущего партия готова каждый год выделять из бюджета 50 млрд евро. С помощью программы «Защитим климат прямо сейчас» партия планирует к 2030 г. добиться уменьшения выбросов СО2 немецкими предприятиями на 70\%, а к 2035 г. сделать Германию «на сто процентов климатически нейтральной. Со старыми источниками энергии - углем, нефтью и газом будет покончено. В ближайшие четыре года во всех городах страны внедрят 1,5 млн солнечных батарей». Кроме того, «Зеленые» обещают создать в Германии «министерство общества»с миссией продвигать равноправие и феминизм на государственном уровне: «Пришло время фе-

\footnotetext{
${ }^{3}$ Чем программы немецких партий завлекают избирателей // Российская газета [Электронный ресурс]. 2021. 25 августа. URL: https://rg.ru/2021/08/25/chem-programmy-nemeckih-partijzavlekaiut-izbiratelej.html (дата обращения: 01.12.2021).
} 
министического правительства. Это значит: в правительстве не должны быть только мужчины. Или только женщины. В правительстве должны быть представлены все люди. В том числе люди, которые относятся к третьему полу. Чтобы поддерживать меньшинства по всему миру, Германия должна проводить «феминистическую внешнюю политику» ${ }^{4}$.

Такая же более-менее понятная избирателям детализация характерна и для внешнеполитической доктрины «Зеленых». Они обещают сохранять санкции против России, а также выступают против газопровода «Северный поток-2». Звучит и миролюбивая риторика: «Зеленые» призывают НАТО отказаться от концепции «первого удара» и запустить широкую общественную дискуссию об отходе от «устаревших доктрин образца холодной войны». В качестве первого шага для снижения напряженности в Европе партия предлагает «возобновить стратегический диалог и военные контакты между НАТО и РФ» ${ }^{5}$. Результат детализации программных установок «Зеленых» известен - партия стала третьей в статусном списке партий ФРГ.

Партнер СДПГ и «Зеленых» по коалиции - «Свободная демократическая партия» - также привлекла симпатии избирателей целым рядом миролюбивых обещаний. Она выступает против «Северного потока-2», но не столь категорично, требуя не отказываться от проекта, а наложить на него мораторий. При этом партия признает, что «Россия остается близка Германии и Европе по-человечески, культурно и экономически», и предлагает поддерживать с Москвой «диалог по возобновляемым источникам энергии, водороду и синтетическому топливу» ${ }^{6}$.

В то же время избиратели продемонстрировали свое неприятие радикальных, крайне правых идей, олицетворением которых стала программа партии «Альтернатива для Германии». В ней меры правительства по борьбе с эпидемией партия называет избыточными, требуя отменить обязательное ношение масок и «принуждение к вакцинации». В остальном «Альтернатива для Германии» осталась верна своим лозунгам: перестать рассматривать Германию как «рай для мигрантов», ужесточить борьбу с радикальным исламизмом, выйти из

\footnotetext{
${ }^{4}$ Чем программы немецких партий завлекают избирателей // Российская газета [Электронный ресурс]. 2021. 25 августа. URL: https://rg.ru/2021/08/25/chem-programmy-nemeckih-partijzavle kaiut-izbiratelej.html (дата обращения: 01.12.2021).

${ }^{5}$ Там же.

${ }^{6}$ Там же.
} 
Парижского соглашения по климату, ввести «прямую демократию» по образцу референдумов в Швейцарии, вернуться к национальной валюте. «Мы выступаем за выход Германии из ЕС и учреждение нового европейского сообщества на основе общности экономики и интересов... Членство в НАТО, активная роль Германии в ОБСЕ остаются центральным элементом нашей стратегии безопасности - до дальнейшего уведомления. Однако НАТО должна стать чисто оборонным альянсом, чтобы сфера его компетенции ограничивалась исключительно территорией государств-членов... США в настоящее время выступают самым сильным союзником Германии. Суть нашего партнерства должна заключаться в равноправии... Снятие напряжения в отношениях с Россией - залог долгосрочного мира в Европе. В интересах Германии и Европы вовлечь Россию в общую структуру политики безопасности. Мы выступаем за возобновление регулярных переговоров в рамках Совета Россия - НАТО» ${ }^{7}$.

Однако, на примере «Левых» не всегда конкретные политические формулировки приносят успех. Эта партия - наследница Социалистической единой партии Германии, так и осталась верна идеалам интернационализма и «антиимпериализма». Она требует прекратить экспорт вооружений из ФРГ, закрыть авиабазу «Рамштайн» и другие военные объекты США в стране, вывести с территории Германии американское ядерное оружие, а также снять санкции Вашингтона и Брюсселя с Кубы, поддержать преследуемых американской фемидой Ассанжа, Сноудена и всех, кто «открыл миру глаза на преступления США» 8 . Во-вторых, следует отметить негативное влияние личностного фактора на рейтинги ХДС и СДПГ.

Какие бы хвалебные отзывы ни звучали по поводу «эпохи Меркель», ряд политологов и многие простые избиратели Германии оценивают этот период исходя из несколько других позиций. В их понимании одна из важнейших причин падения популярности ХДС и СДПГ - личностный фактор «политического поведения» высшего руководства страны и, в частности, самой А. Меркель. Конечно, следует сразу же оговориться: «эпоха Меркель» - это довольно успешный этап в немецкой истории, и ее заслуга в этом не отрицается.

\footnotetext{
${ }^{7}$ Чем программы немецких партий завлекают избирателей // Российская газета [Электронный ресурс]. 2021. 25 августа. URL: https://rg.ru/2021/08/25/chem-programmy-nemeckih-partijzavle

kaiut-izbiratelej.html (дата обращения: 01.12.2021).

${ }^{8}$ Там же.
} 
Одним из проявлений личностного фактора стала сопровождающая многих других политиков - долгожителей во власти объективная «усталость» избирателей от их манеры навязывать свое мнение и убеждать в его абсолютной правоте. А. Меркель в этом плане не исключение, правда, по-женски в более мягкой форме. Она изменила политический стиль общения, присущий политикам прошлого времени, поставив во главу угла осторожность и компромисс. В начале своего правления эта методика срабатывала, позволяя после провала экономической программы Г. Шрёдера и его конфликтного стиля общения найти с СДПГ общий язык в решении возникших проблем.

Однако с течением времени эта готовность А. Меркель к компромиссам в экономической сфере стала присуща и политической работе правительства, обесцветив его деятельность и превратив ее в бесконечную череду переговоров. Такая манера работы сказалась на принятии многих решений в критические периоды развития страны (финансовый и более поздний миграционный кризис).

При «ранней» А. Меркель это привело к снижению позиции ФРГ в мировом экономическом рейтинге: если в 2005-2006 гг. Германия занимала третье место в мире по размеру ВВП, уступая лишь США и Японии, то в 2007 г. оказалась на четвертом (ее обошел Китай). В 2009 г. немецкая экономика сократилась в годовом выражении на 5,7\% из-за глобального финансового кризиса и долгового кризиса еврозоны, а в 2020 г. ВВП страны сократился на 4,9\% из-за пандемии коронавируса 9 .

На период пребывания А. Меркель во главе правительства пришелся и рекордный приток иммигрантов в послевоенной истории страны, пик которого произошел в 2015 г. (в страну въехали 2 млн иностранцев). Тем не менее, в последующие годы эта цифра снижалась: в 2016 г. - 1,7 млн, в 2017 и 2018 гг. - по 1,4 млн, в 2019 г. - 1,3 млн, в 2020 г. -1 млн человек ${ }^{10}$.

Нерешительность канцлера А. Меркель при принятии ряда государственных решений привела к частичной утрате доверия избирателей к провозглашаемым ХДС политическим лозунгам, что по мнению аналитиков открыло дорогу в большую политику партиям второго эшелона, в том числе левого и крайне правого толка. Во многом это

\footnotetext{
${ }^{9} 16$ лет эпохи Меркель в пяти фактах. Как изменилась Германия с 2005 года // РБК [Электронный ресурс]. 2021. 7 декабря. URL: https://www.rbc.ru/politics/07/12/2021/61125c909 a79470ebfb7f017 (дата обращения: 01.12.2021).

${ }^{10}$ Там же.
} 
было связано с отсутствием в конце «эпохи Меркель» равноценной ей партийной фигуры, способной продемонстрировать качества политического лидера, присущие политикам - мэтрам прошлых эпох.

Применительно к электоральной кампании 2021 г. можно сказать, что ни одна из предлагаемых кандидатур от СДПГ и ХДС на пост канцлера никак не соответствовала представлениям большинства избирателей о своем будущем руководителе государства, считая их неприемлемыми.

Об этом, в частности, свидетельствует ход процедуры выбора кандидата от ХДС на пост канцлера - А. Лашета или М. Зедера. Как отмечает немецкий политолог А. Рар, «там внутри ХДС - разброд и шатания. Там есть силы, которые хотят заменить А. Лашета на более популярного премьера Баварии М. Зедера. Все это отражается на рейтинге А. Лашета и его партии. Многие по этой причине всерьез задумываются проголосовать за социал-демократов, «Зеленых» или СвДП. Большой вопрос, получится ли у А. Лашета проводить политику в стиле А. Меркель - усидеть сразу на всех стульях» ${ }^{11}$.

Кроме того, очевидной тенденцией стали массовые переходы избирателей из одной партии в другую. Приведем краткую статистику таких переходов (сравнение 2021 и 2017 гг.). К СДПГ перешли 1,99 млн сторонников ХДС/ХСС, 1,25 млн «не-избирателей», которые не ходили на выборы ранее (Nichtwähler), 820 тыс. левых, 700 тыс. зелёных, 520 тыс. СвДП, 420 тыс. АдГ и 310 тыс. получивших право голоса (новичков на выборах); к ХДС/ХСС - 830 тыс. СвДП, 960 тыс. «не-избирателей», 490 тыс. АДГ, 460 тыс. СДПГ, 210 тыс. новичков, 130 тыс. зелёных, 110 тыс. левых; к зелёным - 1,05 млн ХДС/ХСС, 960 тыс. СДПГ, 610 тыс. левых, 510 тыс. «не-избирателей», 460 тыс. новичков, 370 тыс. СвДП, 80 тыс. АдГ; к СвДП - 1,32 млн ХДС/ХСС, 480 тыс. «не-избирателей», 400 тыс. новичков, АдГ, 340 тыс. СДПГ, 160 тыс. левых, 130 тыс. зелёных ${ }^{12}$.

Как видим, за четыре года численность сторонников ХДС и СДПГ исчислялась миллионным потерями. Это серьезный повод для

\footnotetext{
${ }^{11}$ Кулагин В. Партия Меркель сдает. Кто составит ей конкуренцию на выборах в Германии // gazeta.ru [Электронный ресурс]. 2021. 23 августа. URL: https://www.gazeta.ru/politics/2021/08/ 23_a_13906124.shtml (дата обращения: 01.12.2021).

12 Белов В.Б. Значение выборов в Бундестаг для внутри- и внешнеполитических процессов в ФРГ и российско-германских отношений // Аналитические записки Института Европы РАН [Электронный ресурс]. 2021. Вып. 28. URL: https://www.gazeta.ru/politics/2021/08/23_a_ 13906124.shtml (дата обращения: 01.12.2021).
} 
нового поколения их партийных руководителей задуматься о политических перспективах своих партий.

Обсуждение результатов. Основные результаты исследования проблемы представлены на 20-й международной научной конференции «Беларусь в современном мире», проходившей на факультете международных отношений ФМО БГУ 29 октября 2021 г., а также будут внедрены в учебный процесс в ходе преподавания специального курса «ФРГ, Австрия и Швейцария: политические системы и внешняя политика».

Выводы. В заключение необходимо сформулировать и представить следующие выводы:

Во-первых, закономерным и предсказуемым результатом избирательной кампании 2021 г. стал массовый переток разочарованных избирателей из «своей партии» в другую, более надежную партию, что позволяет говорить о кризисе традиционной двухпартийной модели ФРГ, существовавшей на протяжении многих десятилетий, но устаревшей сегодня.

Во-вторых, ни одна из политических партий не смогла выдвинуть популярного и харизматичного лидера, который стал бы однозначным и бесспорным фаворитом избирательной компании. Это затрудняет поиск такой модели дальнейшего развития германского общества, а также изменений во внутренней и внешней политике ФРГ, которые бы соответствовали современным вызовам и тенденциям.

B-третьих, за последние 20 лет на электоральном поле Германии произошли кардинальные сдвиги в расстановке политических сил, суть которых в центробежном смещении концептуальных позиций ведущих партий ФРГ и все большем завоевании места на политическом поле страны относительно новыми партиями левого, правого и крайне правого толка.

\section{Библиографические ссылки}

1. Павлов Н. В. Внешняя политика канцлера А. Меркель (2005-2017). М.: МГИМОУниверситет, 2018. $388 \mathrm{c.}$

2. Фрольцов B. B. Внешнеполитические цели и задачи четвертого правительства А. Меркель // Журн. междунар. права и междунар. отношений. 2017. № 3-4 (82-83). С. 10-18.

3. Фрольцов В. В. Постсоветские государства во внешней политике ФРГ (1991-2005). Минск: БГУ, 2013. $431 \mathrm{c.}$

4. Фрольцов В.В. Реакция ФРГ на «цветные революции» в постсоветских государствах (2003-2005) // Актуальные проблемы международных отношений и глобального развития: сб. науч. ст. Минск: БГУ, 2014. Вып. 2. С. 91-104. 
5. Шарапо A. В. Избирательная кампания 2017 г. в Германии: особенности межпартийной борьбы и проблемы формирования правительства: учеб. матер. для студентов. Минск: БГУ, $2018.95 \mathrm{c}$.

6. Шарапо A. B. Особенности транзита власти в ФРГ: уроки прошлого и современность // Актуальные проблемы международных отношений и глобального развития: сб. науч. ст. Вып. 8. Минск, 2020. С. 119-133.

7. Шарапо A. B. Политические системы и внешняя политика Германии, Австрии и Швейцарии: учеб. пособие. Минск: БГУ, 2007. 231 с.

8. Шарапо A. В. ФРГ после выборов в Бундестаг 2017 г. в поиске новой модели развития // Историческая германистика: актуальные проблемы современных исследований: сб. научных статей и материалов. Псков: ООО «ЛОГОС», 2018. С. 238-245.

9. Фёдоров В. П. Экономика и политика Германии: через год после выборов. М.: Ин-т Европы РАН, 2019. 134 с.

10. Froltsov $V . V$. Germany's foreign policy in the context of the multilateralism crisis in the 2010s: the main challenges and risks // Веснік Брэсцкага ўніверсітэта. Серыя 2. Гісторыя. Эканоміка. Права. 2019. № 1. С. 20-29.

11. Froltsov $V$. $V$. Russia, Ukraine, Belarus in the program documents of the three governments of Angela Merkel (2005-2017) // J. Belarus. State Univ. Int. Relat. 2018. No. 1. Pp. 3-9.

12. Froltsov $V$. V. The Eastern and Southeastern European countries in the pre-election programs of the key German parties 2017 // J. Belarus. State Univ. Int. Relat. 2017. No. 2. Pp. 24-30.

Дата поступления статьи: 01.12.2021.

Автор: Шарапо Александр Викторович - доктор исторических наук, профессор кафедры международных отношений факультета международных отношений Белорусского государственного университета.

\title{
NEW TRENDS IN THE ALIGNMENT OF POLITICAL FORCES IN GERMANY (ON THE EXAMPLE OF THE ELECTION CAMPAIGN IN 2021)
}

\author{
A. V. SHARAPA \\ Belarusian State University, \\ Minsk, Republic of Belarus
}

\begin{abstract}
The article provides a comparative analysis of the results of the parliamentary elections in Germany in 2021. The author also examines the consequences of this election campaign, which consisted in a significant change in the political potential of the leading German parties, the departure from the political life of Germany of the long-term Chancellor A. Merkel and the formation of a new ruling coalition. The new government of Germany included three political parties: the Social Democrats, the Free Democrats and the Greens. The SPD leader Olaf Scholz was elected as Federal Chancellor and presented a government program aimed at promoting the updated development strategy of the Federal Republic of Germany in the coming decades.
\end{abstract}


Despite the fact that the analysis of the results and consequences of the parliamentary elections in Germany in 2021 is of considerable interest for a comprehensive study by various researchers, the relevance and novelty of the events and processes that took place in Germany in the spring and autumn of 2021 determine their clearly insufficient coverage in scientific publications.

Results and consequences of the 2021 election campaign require further comprehensive research due to their importance for determining the future directions of both domestic and foreign policy of modern Germany, which is capable of having a significant impact on European and World politics, including defining the EU development strategy and influencing the decisions of other European states.

Key words: Germany; domestic policy of Germany; SPD; CDU; Greens; The FDP; parliamentary elections; ruling coalition.

For citations: Sharapa A. V. (2021). Novye tendencii v rasstanovke politicheskih sil FRG (na primere izbiratel'noj kampanii 2021 g.) [New trends in the alignment of political forces in Germany (on the example of the election campaign in 2021)]. In: Actual problems of international relations and global development: collection of scientific papers. Minsk, Vol. 9, p. 37-53. https://doi.org/10.33581/2311-9470-2021-9-3753

\section{References}

1. Pavlov N. V. (2018). Vneshniaia politika kantslera A. Merkel' (2005-2017) [Foreign policy of Chancellor Angela Merkel (2005-2017)]. Moscow, MGIMO-University, 388 p. (In Russ.).

2. Froltsov V. V. (2017). Vneshnepoliticheskie tseli i zadachi chetvertogo pravitel'stva A. Merkel' [Foreign policy goals and objectives of the fourth government of Angela Merkel]. In: J. Int. Law \& Int. Relat. 3-4 (82-83), pp. 10-18. (In Russ.).

3. Froltsov V. V. (2013) Postsovetskie gosudarstva vo vneshnei politike FRG (1991-2005) [PostSoviet states in the foreign policy of Germany (1991-2005)]. Minsk, BSU. 431 p. (In Russ.).

4. Froltsov V. V. (2014) Reaktsiia FRG na «tsvetnye revoliutsii» v postsovetskikh gosudarstvakh (2003-2005) [The German reaction to the "color revolutions" in the post-Soviet states (20032005)]. In: Actual problems of international relations and global development: collection of scientific papers. Minsk, Vol. 2, pp. 91-104. (In Russ.).

5. Sharapa A. V. (2018). Izbiratel'naia kampaniia 2017 g. v Germanii: osobennosti mezhpartiinoi bor'by i problemy formirovaniia pravitel'stva: uchebnye materialy dlia studentov. [The 2017 election campaign in Germany: features of the inter-party struggle and the problems of government formation: reader for students]. Minsk, BSU, 95 p. (In Russ.).

6. Sharapa A. V. (2020). Osobennosti tranzita vlasti v FRG: uroki proshlogo i sovremennost'. [Key features of power transit in Germany: lessons of the past and modernity]. In: Actual problems of international relations and global development: collection of scientific papers. Minsk, Vol. 8, pp. 119-133. (In Russ.).

7. Sharapa A. V. (2007). Politicheskie sistemy i vneshnjaja politika Germanii, Avstrii i Shvejcarii: uchebnye materialy dlia studentov. [Political systems and foreign policy of Germany, Austria and Switzerland: reader for students]. Minsk, BSU, 231 p. (In Russ.).

8. Sharapa A. V. (2018). FRG posle vyborov v Bundestag 2017 g. v poiske novoj modeli razvitija. [Germany after the 2017 Bundestag elections in search of a new development model]. In: Historical German Studies: Actual Problems of Contemporary Research. Vol. of articles and materials. Pskov, Logos, pp. 238-245. (In Russ.). 
9. Fiodorov V. P. (2019). Jekonomika i politika Germanii: cherez god posle vyborov. [German Economy and Politics: One Year After the Elections]. Moscow: Europe Institute of the Russian Academy of Sciences, 134 p. (In Russ.).

10. Froltsov, V. V. (2019). Germany's foreign policy in the context of the multilateralism crisis in the 2010s: the main challenges and risks. In: Vesnik of Brest University. Series 2. History. Economics. Law. 1. Pp. 20-29.

11. Froltsov V. V. (2018). Russia, Ukraine, Belarus in the program documents of the three governments of Angela Merkel (2005-2017). In: J. Belarus. State Univ. Int. Relat. 1. Pp. 3-9.

12. Froltsov V. V. (2017). The Eastern and Southeastern European countries in the pre-election programs of the key German parties 2017. In : J. Belarus. State Univ. Int. Relat. 2. Pp. 24-30.

About author: Sharapa Aliaksandr Viktaravich - Doctor of Sciences in History (Dr. Hab.), Professor of the Department of International Relations of the Faculty of International Relations, Belarusian State University (Minsk); e-mail: sharapa@bsu.by.

Received: 01.12.2021. 